\title{
Three new fossil records of Equisetum (Equisetaceae) from the Neogene of south-western China and northern Vietnam
}

\author{
Aye Thida Aung 1,2,3, Jian Huang', Truong Van $\mathrm{Do}^{4,5}$, Ai Song ${ }^{1,6}$, \\ Jia Liu', Zhe-Kun Zhou, ${ }^{1,7}$, Tao Su, ${ }^{1,2,3}$
}

I CAS Key Laboratory of Tropical Forest Ecology, Xishuangbanna Tropical Botanical Garden, Chinese Academy of Sciences, Mengla 666303, China 2 University of Chinese Academy of Sciences, Beijing 100049, China 3 Southeast Asia Biodiversity Research Institute, Chinese Academy of Sciences, Yezin, Nay Pyi Taw 05282, Myanmar 4 Vietnam National Museum of Nature, Vietnam Academy of Science and Technology, Hanoi, 100803, Vietnam 5 Graduate University of Science and Technology, Vietnam Academy of Science and Technology, 18 Hoang Quoc Viet, Hanoi, Vietnam 6 Research Center for Earth System Science, Yunnan University, Kunming 650500, China 7 CAS Key Laboratory for Plant Diversity and Biogeography of East Asia, Kunming Institute of Botany, Chinese Academy of Sciences, Kunming 650204, China

Corresponding author: Tao Su (sutao@xtbg.org.cn)

Academic editor: Nianhe Xia | Received 31 July 2019 | Accepted 11 October 2019 | Published 10 January 2020

Citation: Aung AT, Huang J, Do TV, Song A, Liu J, Zhou Z-K, Su T (2020) Three new fossil records of Equisetum (Equisetaceae) from the Neogene of south-western China and northern Vietnam. In: Jin X-H, Xia N-H, Tan Y-H (Eds) Plant diversity of Southeast Asia-II. PhytoKeys 138: 3-15. https://doi.org/10.3897/phytokeys.138.38674

\begin{abstract}
Three fossil species of Equisetum (Equisetaceae) were reported from the Neogene of south-western China and northern Vietnam, based on well-preserved rhizomes with tubers. Equisetum cf. pratense Ehrhart from the middle Miocene of Zhenyuan County, Yunnan Province, China is characterised by a bunch of three ovate tubers with longitudinal ridges on the surface. Equisetum yenbaiense A.T. Aung, T. Su, T.V. Do \& Z.K. Zhou, sp. nov. from the late Miocene of Yenbai Province, Vietnam is characterised by four bunches of elongate tubers arranged in a whorl on a node. Equisetum yongpingense A.T. Aung, T. Su \& Z.K. Zhou, sp. nov. from the late Pliocene of Yunnan is characterised by fibrous roots on most nodes and two to four bunches of large cylindrical tubers arranged in a whorl on a node. Floristic assemblages suggest that these species might have grown near a riverside or lakeshore. These new fossil records improve our understanding of species richness of Equisetum and their distribution range during the Neogene in Asia.
\end{abstract}

\section{Keywords}

Diversity, Equisetum, Miocene, Pliocene, rhizome tubers

Copyright Aye Thida Aung et al. This is an open access article distributed under the terms of the Creative Commons Attribution License (CC BY 4.0), which permits unrestricted use, distribution, and reproduction in any medium, provided the original author and source are credited. 


\section{Introduction}

The order Equisetales, including Calamitaceae, Tchernoviaceae, Gonduanostachyaceae and Equisetaceae, has a very long evolutionary history that can be dated back to the Devonian (Gu and Shi 1974; Wang et al. 2005). Amongst the families, only Equisetaceae is extant. The earliest fossil record of Equisetaceae could be traced back to the Carboniferous, with Equisetites hemingwayii from the early Pennsylvanian of Yorkshire, UK (Kidston 1883). Equisetum (Horsetails) is the only living genus in the family Equisetaceae, with about 15 species distributed widely around the world, except for Antarctica (Kenrick and Crane 1997). It is characterised by hollow aerial stems with nodes and reduced leaves, which are similar to their arborescent ancestors. Equisetum laterale from the Middle Triassic of Australia is the oldest fossil species in Equisetum (Gould 1968). Even some Equisetumlike fossils from the Mesozoic have been identified as Equisetum, the divergence of Equisetum species occurred during the late Eocene $(-40 \mathrm{Ma})$ according to molecular data, with the main radiation during the Neogene (Des Marais et al. 2003; Elgorriaga et al. 2018).

In Equisetum fossils, tuberous rhizomes are the most commonly preserved organ in the Cenozoic strata around the world, such as in North America (Lesquereux 1878; Bell 1949; Becker 1969; Skog and Dilcher 1994), Europe (Watson and Batten 1990; Denk et al. 2005) and Asia (Kon'no 1962; Wu 1999; Sun et al. 2001). In China, the fossil records are rich, but most fossils are limited in northern China, for examples, in the Lower Cretaceous Yixian Formation and Fuxin Formation in Liaoning (Chen et al. 1988; Sun et al. 2001), the Lower Cretaceous Muling Formation of Jixi Basin, Heilongjiang (Yang 2003) and the Middle Eocene Hunchun Formation in Jilin (Guo 2000). In south-western China, only four fossil records of Equisetum have been found, i.e. Equisetum cf. oppositum from the Paleocene-Eocene of the Niubao Formation in Nima Basin, northern Tibet (Yang et al. 2016), Equisetum oppositum from the Lower Oligocene Lawula Formation in eastern Tibet (Ma et al. 2012), Equisetum cf. pratense from the Lower Oligocene of Lühe coal-mine in south-central Yunnan (Zhang et al. 2007) and Equisetum sp. from the Middle Miocene Wulong Formation in southern Tibet (Geng and Tao 1982).

Although some species of Equisetum still survive in Asia nowadays, such as Equisetum diffusum, Equisetum hyemale and Equisetum pratense, its fossil records remain limited, especially during the Neogene. In this study, we describe three fossil species of Equisetum from the Neogene of south-western China and northern Vietnam. Further, we discuss the ecological and biogeographic implications, based on these new fossil records.

\section{Materials and methods}

\section{Fossil localities}

Zhenyuan, south-western China (the middle Miocene). A fossil was found in the Dajie Formation, Sanzhangtian Village, Zhenyuan County, central Yunnan Province, south-western China (Fig. 1). The Dajie Formation, which is mainly distributed in 
central Yunnan, is assigned to the middle Miocene in age, based on lithological and palynological comparisons (Bureau of Geology and Mineral Resources of Yunnan Province (BGMRYP) 1990). Fossil in this study is from light yellow mudstone of the upper layer in the stratum. Many plant fossil species have been previously reported from the same site, including Palaeosorum ellipticum (Jacques et al. 2013), Bambusium angustifolia, B. latifolia, Bambusiculmus angustus, B. latus (Wang et al. 2013), Celastrus caducidentatus (Liang et al. 2016a), Populus zhenyuanensis (Liang et al. 2016b), Cladium zhenyuanensis (Liang et al. 2017), Zygogynum poratus (Liang et al. 2018), and Metasequoia cf. glyptostroboides (Wang et al. 2019).

Yen Bai, northern Vietnam (the late Miocene). Fossils were found in the Co Phuc Formation, Hop Thanh Village, Tuy Loc Commune, Yen Bai Province, northern Vietnam (Fig. 1). The fossil site is situated in the Yen Bai Basin along the Red River Fault Zone, which is a main Cenozoic strike-slip zone in Southeast Asia. The Co Phuc Formation belongs to the late Miocene in age which mainly consists of siltstone and fine sandstone (Wysocka and Świerczewska 2010). The fossils included in this study were collected from the yellow siltstone of the upper layer. Plant fossils such as Polypodiaceae, Palmae and Lauraceae have been previously reported from the fossil site (Zeiller 1903; Colani 1920).

Yongping, south-western China (the late Pliocene). The fossils were found in the Sanying Formation, Longmen Village, Yongping County, Yunnan Province, south-western China (Fig. 1). According to a recent paleomagnetic study, the Sanying Formation was dated from the late Miocene to the early Pleistocene (Li et al. 2013). This formation is widely distributed in western and north-western Yunnan Province (BGMRYP 1990). Fossils here are from siltstone in the middle part of the stratum, which is dominated by Quercus section Heterobalanus (evergreen sclerophyllous oak) (Su 2010). Some other species, including Drynaria callispora (Su et al. 2011) and Cedrus angusta (Su et al. 2013b) have been reported from the same site. According to paleoclimate reconstruction using leaf assemblage of the flora, a warmer and more humid climate than nowadays existed in western Yunnan during the late Pliocene (Su et al. 2013a).

\section{Morphological observation}

Equisetum fossils were imaged to view gross morphology by using a digital camera (Nikon D700) with a Kaiser 5510 stand and oblique light. To observe morphological characters in detail, fossils were photographed by stereoscope microscopes (Leica A8APO and ZEISS Smart Zoom 5). The contrast of images was slightly adjusted using the software Adobe Photoshop (version CC 2018). Morphological characters were measured by ImageJ (version 1.52). For comparison with previously published fossil taxa, we checked fossil records from online databases, for examples, Web of Science and Google Scholar. All fossil specimens in this study are deposited in the Paleoecology Collections, Xishuangbanna Tropical Botanical Garden, Chinese Academy of Sciences and Vietnam National Museum of Nature, Vietnam Academy of Science and Technology. 


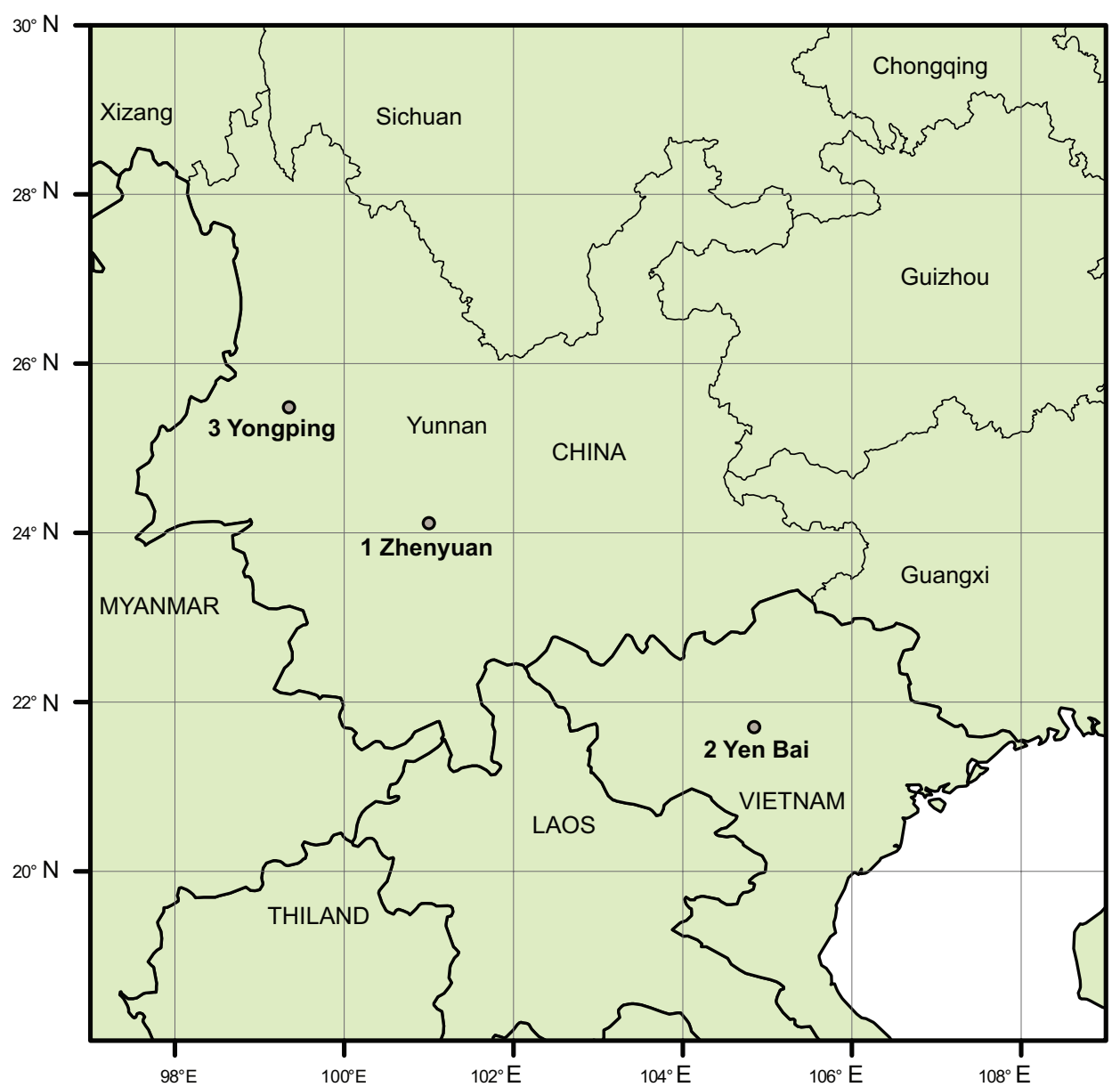

Figure I. Map showing the locations of the fossils collected in this study. 1. Sanzhangtian, Zhenyuan County, Yunnan, south-western China (the middle Miocene); 2. Hop Thanh Village, Tuy Loc Commune, Yen Bai Province, northern Vietnam (the late Miocene); 3. Longmen, Yongping County, Yunnan Province, south-western China (the late Pliocene).

\section{Results}

Order Equisetales Dumortier

Family Equisetaceae A. Michaux ex Alph. De Candolle

Genus Equisetum Linnaeus

Equisetum fossils from Zhenyuan, south-western China

\section{Equisetum cf. pratense Ehrhart}

Specimens checked. XTBGSZTF0001 (Fig. 2A-B)

Locality. Dajie Formation, Sanzhangtian Village, Zhenyuan County, central Yunnan Province, South-western China (24.100N, 101.216E). 

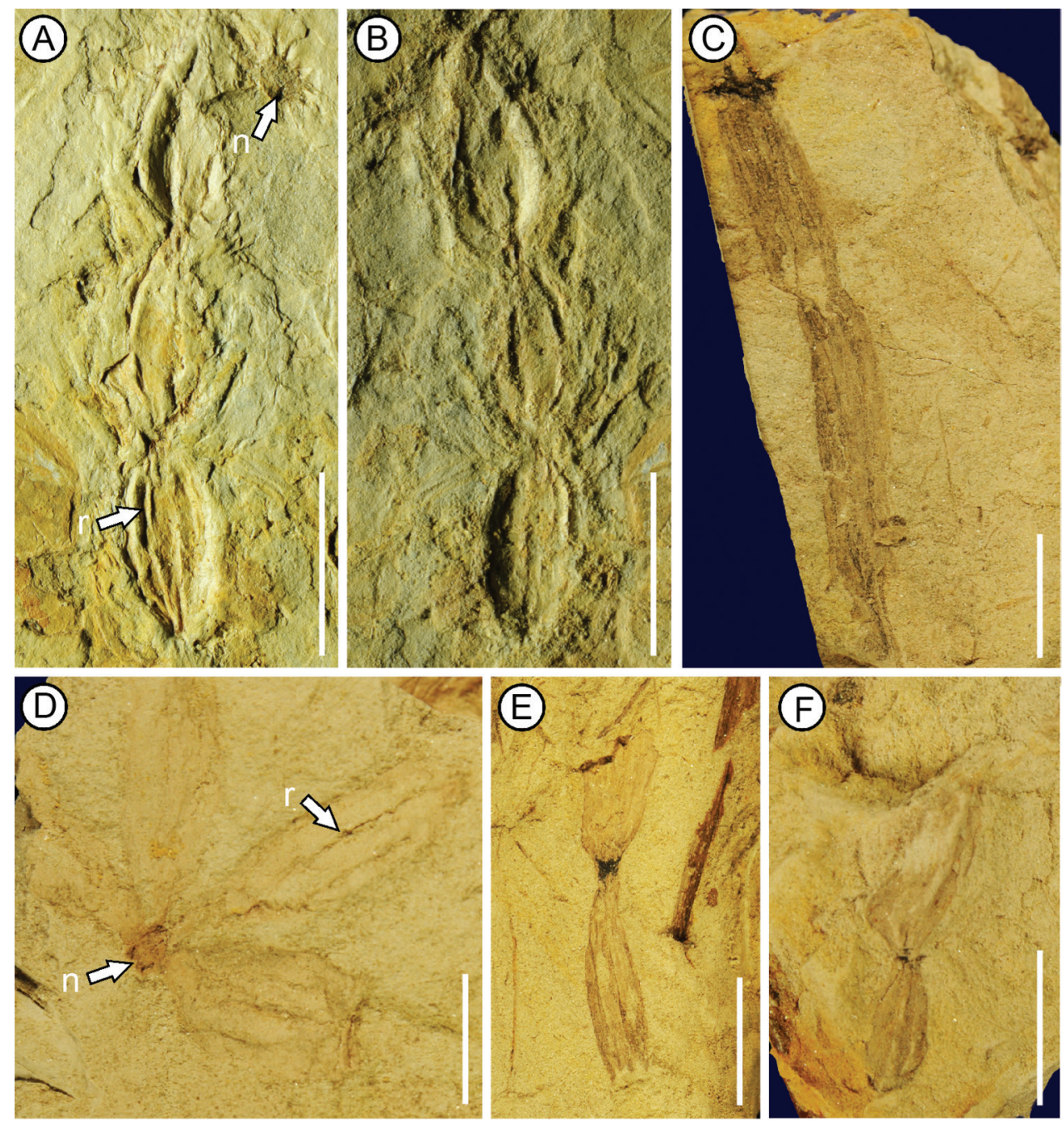

Figure 2. A-B Equisetum cf. pratense Ehrhart C-F Equisetum yenbaiense A.T.Aung, T.Su, T.V.Do \& Z.K.Zhou, sp. nov. Specimen numbers: A-B XTBGSZTF0001 (counterparts) C XTBGVNMN4002 D XTBGVNMN4001 EXTBGVNMN4003 F XTBGVNMN4004. $\mathbf{n}=$ node; $\mathbf{r}=$ ridge. $S$ cale bars: $1 \mathrm{~cm}$.

Age. The middle Miocene.

Repository. Paleoecology Collections, Xishuangbanna Tropical Botanical Garden, Chinese Academy of Sciences.

Description. Only one bunch of tubers are preserved on the specimen, tubers are ovate in shape, three tubers of equal size are arranged in one row (Fig. 2A-B). The length and width of the tubers are -0.9 to $1.2 \mathrm{~cm}$ and 0.6 to $0.8 \mathrm{~cm}$, respectively. Two to three longitudinal ridges are present on the surface of each tuber (Fig. 2A-B). The tip of the tuber is mucronate (Fig. 2A-B). These characters fit well within the morphology of $E$. cf. pratense, a fossil species reported from the early Oligocene in the Lühe coal-mine, south-central Yunnan (Zhang et al. 2007; Linnemann et al. 2018). 
Equisetum fossils from Yen Bai, northern Vietnam

Equisetum yenbaiense A.T.Aung, T.Su, T.V.Do \& Z.K.Zhou, sp. nov.

Holotype. XTBGVNMN4001 (Fig. 2D).

Paratypes. XTBGVNMN4002-4004 (Fig. 2C, E-F).

Locality. Hop Thanh Village, Tuy Loc Commune, Yen Bai Province, northern Vietnam $(21.725 \mathrm{~N}, 104.849 \mathrm{E})$.

Age. The late Miocene.

Repository. Paleoecology Collections, Xishuangbanna Tropical Botanical Garden, Chinese Academy of Sciences and Vietnam National Museum of Nature, Vietnam Academy of Science and Technology.

Etymology. The species name 'yenbaiense' means that fossils are from Yen Bai Province, northern Vietnam.

Diagnosis. Rhizomes with internodes and nodes, node round; Four bunches of tubers arranged in a whorl on a node (Fig. 2D); most tubers elongate in shape, with one to two tubers in each bunch (Fig. 2C-D); longitudinal ridges on the surface of tuber; the tip of tuber mucronate (Fig. 2F).

Description. Rhizomes have both internodes and nodes (Fig. 2D). The internode is $-0.2-0.3 \mathrm{~cm}$ in width, the length could not be observed, three longitudinal ridges are on the surface of the internode (Fig. 2D). The node is round and $-0.2 \mathrm{~cm}$ in diameter (Fig. 2D). Four bunches of tubers attach to one node and arrange in a whorl (Fig. 2D). Only one tuber is preserved on each bunch, but it is likely that there are more than one tuber on each bunch (Fig. 2E-F). Most tubers are elongate (Fig. 2D); few are elliptical (Fig. 2F), being -0.8 to $3.0 \mathrm{~cm}$ long and 0.4 to $1.0 \mathrm{~cm}$ wide. Two to four ridges are on the surface of each tuber (Fig. 2D). The tip of tuber is mucronate (Fig. 2F).

Equisetum fossils from Yongping, South-western China

Equisetum yongpingense A.T.Aung, T.Su \& Z.K. Zhou, sp. nov.

Holotype. XTBGYP0748 (Fig. 3A).

Paratypes. XTBGYP0747 (Fig. 3B), XTBGYP1014 (Fig. 3C), XTBGYP1015 (Fig. 3D), XTBGYP0750 (Fig. 3E), XTBGYP0749 (Fig. 3F).

Locality. Sanying Formation, Longmen Village, Yongping County, western Yunnan Province, south-western China (25.518N, 99.519E).

Age. The late Pliocene.

Repository. Paleoecology Collections, Xishuangbanna Tropical Botanical Garden, Chinese Academy of Sciences.

Etymology. The species name 'yongpingense' means that fossils are from Yongping County, south-western China. 

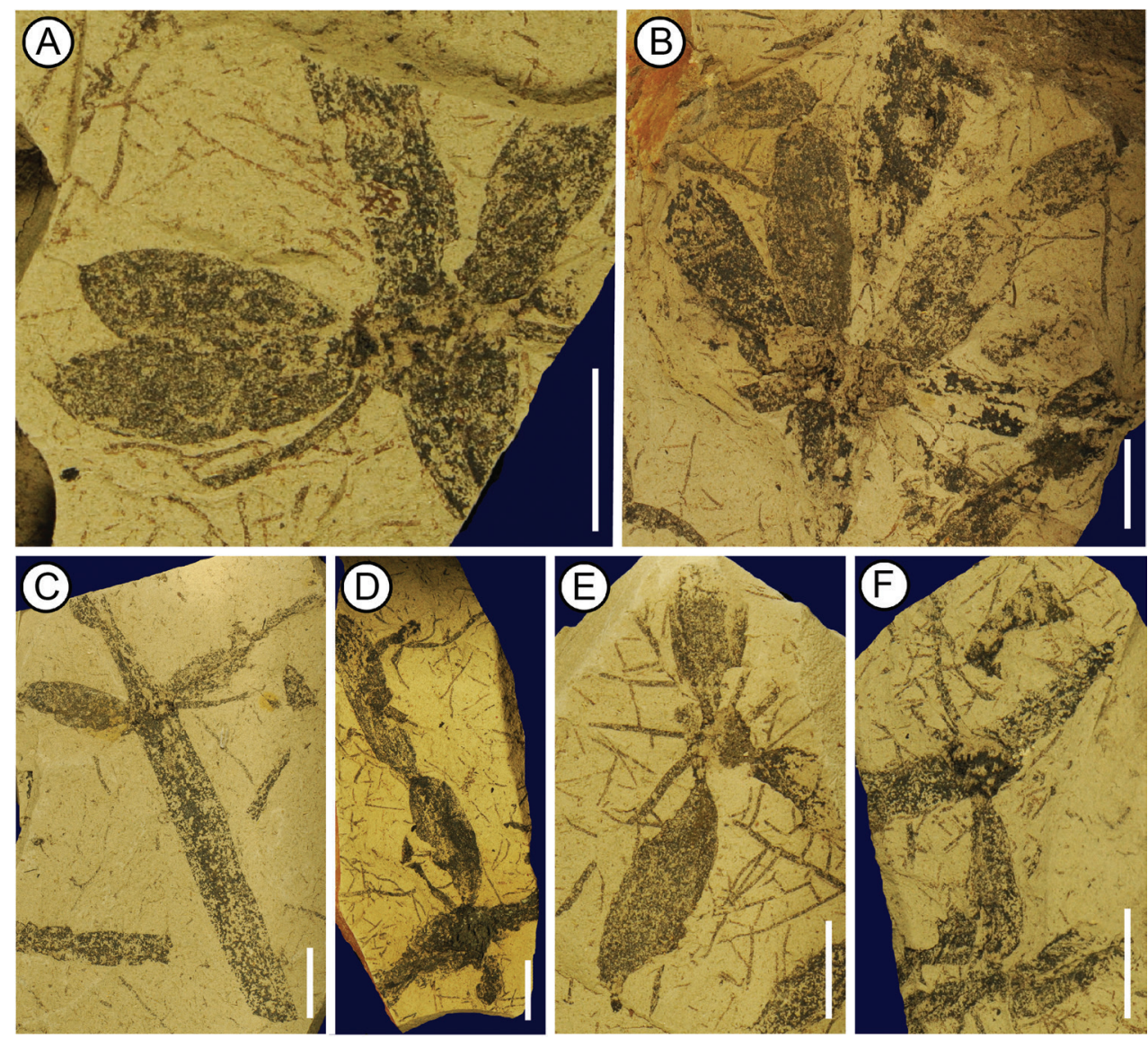

Figure 3. Equisetum yongpingense A.T.Aung, T.Su \& Z.K.Zhou, sp. nov. Specimen numbers: A XTBGYP0748 B XTBGYP0747 C XTBGYP1014 D XTBGYP1015 E XTBGYP0750 F XTBGYP0749. Scale bars: $1 \mathrm{~cm}$.

Diagnosis. Rhizomes with internodes and round nodes; fibrous roots on most nodes; two to four bunches of tubers arranged in a whorl on a node (Fig. 3A); tubers cylindrical in shape, one to two tubers on each bunch (Fig. 3A-B); longitudinal ridges not observed on the surface of tuber; the tip of tuber mucronate (Fig. 3A).

Description. Rhizomes have both internodes and nodes (Fig. 3A). The internode is -0.5 to $0.8 \mathrm{~cm}$ wide, the length is up to $5.1 \mathrm{~cm}$ (Fig. 3A). The node is round and $\sim 0.7$ to $1.0 \mathrm{~cm}$ in diameter (Fig. 3A-B). Most nodes have fibrous roots $\sim 0.1$ to $0.2 \mathrm{~cm}$ wide. Two to six bunches of tubers attach on one node and are arranged in a whorl (Fig. 3A-B). One to two tubers are preserved on each bunch (Fig. 3A-B). Tubers are cylindrical, -1.5 to $3.4 \mathrm{~cm}$ long and 0.6 to $1.2 \mathrm{~cm}$ wide (Fig. 3A-F). Ridges were not observed on the surface of each tuber (Fig. 3A-B, E). The tip of tuber is mucronate (Fig. 3A). 


\section{Discussion}

In this study, we reported three new fossil records of Equisetum from south-western China and northern Vietnam, based on well-preserved rhizomes with tubers. In Equisetum, tubers are the most commonly preserved organ in the fossil records. They are mainly characterised by either a single tuber or one bunch of tubers with longitudinal ridges on the surface, present on fossils we collected (Figs 2-4). These three new fossil records vary in morphological characters, such as the shape and size of tubers (Table 1). They are also different from living species of Equisetum, for example, Equisetum pratense, as they have lager tuber sizes, based on available information (Zhang et al. 2007; Sun et al. 2013).

Equisetum cf. pratense from the middle Miocene of Zhenyuan, south-western China have an ovate tuber shape, which is similar to most fossil records of Equisetum, but different from some fossil species, for example, the tubers of Equisetites longevaginatus are elliptical or round in shape (Table 1). The size of tubers in E. cf. pratense is smaller than other fossil species, such as Equisetum oppositum, Equisetum cf. oppositum and Equisetum hunchunense (Table 1). Generally, all observed morphological characters of the fossil, such as the size and shape of tubers, as well as the mucronate tip of tubers, were in accordance with $E$. cf. pratense, a fossil species previously reported from the early Oligocene of the Lühe coal-mine, south-central Yunnan (Zhang et al. 2007). However, we only found one bunch of tubers at the fossil site, whereas the fossils from the Lühe coal-mine have one to four bunches of tubers with an acervate arrangement on rhizome nodes. More fossils are needed to further determine the arrangement of tubers to better understand the systematic relationship between these two fossil records. Judging by the high morphological similarity, we assign the fossil from Zhenyuan as E. cf. pratense.

For Equisetum yenbaiense from the late Miocene of northern Vietnam, the tuber arrangement is a whorl on a rhizome node, which also occurs in E. hunchunense and $E$. cf. arcticum. However, both $E$. hunchunense and $E$. cf. arcticum have two to three tubers per bunch, whereas $E$. yenbaiense only has one or two tubers per bunch, which might be partly due to the preservation of the fossil. In addition, there are more than three tubers per bunch in E. oppositum and E. cf. oppositum (Table 1). The shape of tubers in $E$. yenbaiense is elongate, the ratio between length and width is higher than most other fossil species, except for $E$. cf. arcticum. We noted that the tuber size in E. yenbaiense is larger than that in E. cf. arcticum (Table 1). Therefore, we designate the new fossil specimens from northern Vietnam as a new species, namely, E. yenbaiense A.T. Aung, T. Su, T.V. Do \& Z.K. Zhou, sp. nov.

In Equisetum yongpingense, there are two to four bunches of tubers arranged in a whorl on a node, which has the same pattern as E. hunchunense and $E$. cf. arcticum. The tip of the tubers is mucronate in E. yongpingense, which is also present on other previously reported fossil species (Table 1). However, the tuber shape of E. yongpingense is cylindrical, which is different from other fossil records. Ridges on the surface of tubers are not prominent in E. yongpingense, whereas ridges are present in other fossil species. 
A

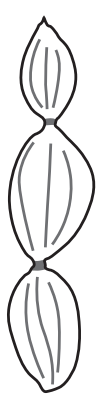

B

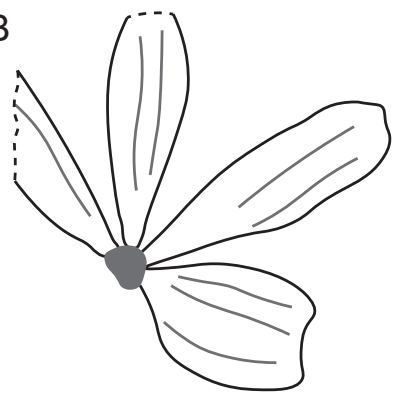

C

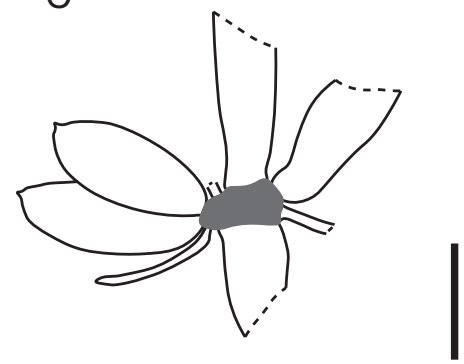

Figure 4. Reconstruction of Equisetum from A Zhenyuan, south-western China, specimen number XTBGSZTF0001 B Yanbei, northern Vietnam, specimen number XTBGVNMN4001; and C Yongping, south-western China, specimen number XTBGYP0748. Scale bar: $1.5 \mathrm{~cm}$.

Table I. Morphological comparisons between new fossil records in this study and previously reported Equisetum and Equisetites fossil species.

\begin{tabular}{|c|c|c|c|c|c|c|c|c|}
\hline Species & \begin{tabular}{|c|} 
Tuber \\
arrangement
\end{tabular} & \begin{tabular}{|c|}
$\begin{array}{c}\text { Number } \\
\text { of tubers } \\
\text { per bunch }\end{array}$ \\
\end{tabular} & Shape of tuber & $\begin{array}{l}\text { Tuber } \\
\text { length } \\
(\mathrm{cm})\end{array}$ & $\begin{array}{l}\text { Tuber } \\
\text { width } \\
\text { (cm) }\end{array}$ & Age & Locality & References \\
\hline Equisetum sp. & $?$ & 3 & Elliptical & $1.0-1.2$ & $0.6-0.8$ & Miocene & Iceland & Denk et al. 2005 \\
\hline $\begin{array}{l}\text { Equisetum } \mathrm{cf} . \\
\text { arcticum }\end{array}$ & Whorl & $2-3$ & $\begin{array}{l}\text { Elongate, ovate, } \\
\text { round }\end{array}$ & $1.5-2.5$ & $0.5-0.7$ & $\begin{array}{l}\text { Oligocene to } \\
\text { Miocene }\end{array}$ & America & Becker 1969 \\
\hline $\begin{array}{l}\text { Equisetum } \\
\text { hunchunense }\end{array}$ & Whorl & $2-3$ & Elliptical, ovate & 1.5 & $0.4-0.9$ & Eocene & China & Guo 2000 \\
\hline $\begin{array}{l}\text { Equisetum } \\
\text { jiuquanense }\end{array}$ & $\begin{array}{l}\text { Single to } \\
\text { acervate }\end{array}$ & $2-3$ & $\begin{array}{l}\text { Elliptical, ovate, } \\
\text { round }\end{array}$ & $0.3-0.8$ & $0.4-0.7$ & $\begin{array}{c}\text { Early } \\
\text { Cretaceous }\end{array}$ & China & Sun et al. 2013 \\
\hline $\begin{array}{l}\text { Equisetites } \\
\text { longevaginatus }\end{array}$ & $\begin{array}{l}\text { Single or } \\
\text { opposite }\end{array}$ & $2-3$ & Elliptical, round & $0.5-0.8$ & $0.3-0.5$ & Cretaceous & China & Sun et al. 2001 \\
\hline $\begin{array}{l}\text { Equisetum } \\
\text { oppositum }\end{array}$ & Opposite & 6 & $\begin{array}{c}\text { Round, elliptical, } \\
\text { ovate }\end{array}$ & $1.0-1.6$ & $0.8-1.2$ & Early Oligocene & China & Ma et al. 2012 \\
\hline $\begin{array}{l}\text { Equisetum cf. } \\
\text { oppositum }\end{array}$ & Single & $5-6$ & $\begin{array}{l}\text { Elliptical, ovate, } \\
\text { and nearly round }\end{array}$ & $1.0-1.6$ & $0.8-1.2$ & $\begin{array}{l}\text { Paleocene- } \\
\text { Eocene }\end{array}$ & China & Yang et al. 2016 \\
\hline $\begin{array}{l}\text { Equisetum } \mathrm{cf} . \\
\text { pratense }\end{array}$ & $?$ & 3 & Ovate & $0.9-1.2$ & $0.6-0.8$ & Middle Miocene & China & This study \\
\hline $\begin{array}{l}\text { Equisetites } \\
\text { vittatus }\end{array}$ & Whorl & $1-2$ & Elliptical, elongate & $0.8-3.0$ & $0.4-1.0$ & Late Miocene & Vietnam & This study \\
\hline $\begin{array}{l}\text { Equisetum } \\
\text { yongpingense }\end{array}$ & Whorl & $1-2$ & Cylindrical & $1.5-3.4$ & $0.6-1.2$ & Late Pliocene & China & This study \\
\hline
\end{tabular}

In E. yongpingense, fibrous roots were also observed on the rhizome node, which is not observed on other fossil species. Therefore, we name these fossil specimens from Yongping as E. yongpingense A.T.Aung, T.Su \& Z.K.Zhou, sp. nov.

The three new fossil records described in this study expand the distribution of $E q$ uisetum during the Neogene in Asia. These findings and previous fossil records indicate that Equisetum has been widely distributed in Asia since the Paleocene and become diverse in Asia since the Oligocene. According to fossil assemblages, Equisetum mainly grew under wet conditions. Other taxa that were reported from the same stratum in Zhenyuan, such as Palaeosorum ellipticum (Jacques et al. 2013), Bambusium angustifolia, B. latifolia, Bambusiculmus angustus, B. latus (Wang et al. 2013) and Metasequoia cf. glyptostroboides (Wang et al. 2019), tend to grow near the riverside or lakeshore. Therefore, we considered that $E$. cf. pratense might favour a similar habitat. In addition, 
E. yongpingense was found in the Upper Pliocene of western Yunnan, where numerous fruits from Trapa, an aquatic plant, had also been found in the same layer ( $\mathrm{Su} 2010)$. Therefore, this habit might have persisted throughout the Cenozoic. Tubers indicate a perennial living form and should contribute to the adaptation of Equisetum under seasonally unfavourable conditions by storing starch (Taiz and Zeiger 2010). Eventually, tubers became important elements in local vegetation, which was evidenced by the abundance of specimens in many fossil sites (Becker 1969; Guo 2000; Ma et al. 2012; Yang et al. 2016).

\section{Acknowledgements}

We thank members from Paleoecology Research Group in Xishuangbanna Tropical Botanical Garden (XTBG), Chinese Academy of Sciences (CAS) for fossil collection; the Public Technology Service Center, XTBG for imaging; Dr. X-Y Liu and Dr. J-Y Wu for reviewing this manuscript and many constructive suggestions. This work is supported by the NSFC (National Natural Science Foundation of China)-NERC (Natural Environment Research Council of the United Kingdom) joint research programme (41661134049 and NE/P013805/1), the National Natural Science Foundation of China (41922010, U1502231, 31800183), Strategic Priority Research Programme of CAS (XDA20070301 and XDB26000000), Natural Science Foundation of Yunnan Province (2019FB026), and Southeast Asia Biodiversity Research Institute, Chinese Academy of Sciences (CAS-SEABRI) (No. Y4ZK111B01).

\section{References}

Becker HF (1969) Fossil plants of the Tertiary Beaverhead basins in southwestern Montana. Palaeontographica Abteilung B 127: 1-142.

Bell WA (1949) Uppermost Cretaceous and Paleocene floras of western Alberta. Geological Survey of Canada. Bulletin 13: 1-231. https://doi.org/10.4095/101514

Bureau of Geology and Mineral Resources of Yunnan Province (BGMRYP) (1990) Regional Geology of Yunnan Province. Geological Publishing House, Beijing.

Chen F, Meng XY, Ren SQ, Wu CL (1988) The Early Cretaceous flora of Fuxin and Tiefa Basin, Liaoning Province. Geological Publishing, Beijing.

Colani M (1920) Étude sur les flores Tertiaires de quelquesgisements de lignite del' Indochineet Yunnan. Bulletin Survey Geologique Indochine 8(1): 1-58. https://doi.org/10.5962/bhl. title. 113040

Denk T, Grimsson F, Kvaček Z (2005) The Miocene floras of Iceland and their significance for late Cainozoic North Atlantic biogeography. Botanical Journal of the Linnean Society 149(4): 369-417. https://doi.org/10.1111/j.1095-8339.2005.00441.x

Des Marais DL, Smith AR, Donald MB, Kathleen MP (2003) Phylogenetic relationships and evolution of extant horsetails, Equisetum, based on chloroplast DNA sequence data 
( $r b c L$ and $t r n L-F)$. International Journal of Plant Sciences 164(5): 737-751. https://doi. org/10.1086/376817

Elgorriaga A, Escapa IH, Rothwell GW, Tomescu AMF, Ruben Cuneo N (2018) Origin of Equisetum: Evolution of horsetails (Equisetales) within the major euphyllophyte Glade Sphenopsida. American Journal of Botany 105(8): 1286-1303. https://doi.org/10.1002/ ajb2.1125

Geng GC, Tao JR (1982) Tertiary plants from Xizang. Nanjing Institute of Geology and Palaeontology and Institute of Botany. Paleontology of Xizang. Science Press, Beijing, 110-125.

Gould RE (1968) Morphology of Equisetum laterale Phillips, 1829, and E. bryanii sp. nov. from the Mesozoic of south-eastern Queensland. Australian Journal of Botany 16(1): 153-176. https://doi.org/10.1071/BT9680153

Gu Z, Shi L (1974) Fossil plants of China (volume l), Palaeozoic plants from China. Science Press, Beijing.

Guo SX (2000) New material of the Late Cretaceous flora from Hunchun of Jilin, Northeast China. Acta Palaeontologica Sinica 39(suppl.): 226-250.

Jacques FMB, Su T, Zhou ZK (2013) The first fossil Microsoroid fern (Palaeosorum ellipticum gen. et sp. nov.) from the middle Miocene of Yunnan, SW China. Journal of Systematics and Evolution 51(6): 758-764. https://doi.org/10.1111/jse.12030

Kenrick P, Crane PR (1997) The origin and early diversification of land plants: A cladistic study. Smithsonian Institution Press, Washington DC.

Kidston R (1883) On the affinities of the genus Pothocites, Paterson; with the description of a specimen from Glencartholm, Eskdale. Annals \& Magazine of Natural History 65(65): 297-314. https://doi.org/10.1080/00222938309459157

Kon'No E (1962) Some species of Neocalamites and Equisetites in Japan and Korea. Science Reports of the Tohoku University 5: 24-47.

Lesquereux L (1878) Contributions to the fossil flora of the western territories. II. The Tertiary flora. In: Hayden FV (Ed.) Report of the US Geological Survey. Government Printing Office, Washington DC, 67-69.

Li SH, Deng CL, Yao HT, Huang S, Liu CY, He HY, Pan YX, Zhu RX (2013) Magnetostratigraphy of the Dali Basin in Yunnan and implications for late Neogene rotation of the southeast margin of the Tibetan Plateau. Journal of Geophysical Research. Solid Earth 118(3): 791-807. https://doi.org/10.1002/jgrb.50129

Liang XQ, Ferguson DK, Su T, Zhou ZK (2016a) Fossil leaves of Populus from the Middle Miocene of Yunnan, SW China. Journal of Systematics and Evolution 54(3): 264-271. https://doi.org/10.1111/jse.12193

Liang XQ, Ferguson DK, Jacques FMB, Su T, Wang L, Zhou ZK (2016b) A new Celastrus species from the middle Miocene of Yunnan, China and its palaeoclimatic and palaeobiogeographic implications. Review of Palaeobotany and Palynology 225: 43-52. https://doi. org/10.1016/j.revpalbo.2015.11.005

Liang XQ, Lu P, Tiwari A, Su T, Zhou ZK (2017) New fossil record of Cladium (Cyperaceae) from the Middle Miocene of Zhenyuan, SW China, and the palaeobiogeographical history of the genus. Review of Palaeobotany and Palynology 237: 1-9. https://doi.org/10.1016/j. revpalbo.2016.10.006 
Liang XQ, Lu P, Zhang JW, Su T, Zhou ZK (2018) First fossils of Zygogynum from the Middle Miocene of Central Yunnan, Southwest China, and their palaeobiogeographic significance. Palaeoworld 27(3): 399-409. https://doi.org/10.1016/j.palwor.2018.05.003

Linnemann U, Su T, Kunzmann L, Spicer RA, Ding WN, Spicer TEV, Zieger J, Hofmann M, Moraweck K, Gärtner A, Gerdes A, Marko L, Zhang ST, Li SF, Tang H, Huang J, Mulch A, Mosbrugger V, Zhou ZK (2018) New U-Pb dates show a Paleogene origin for the modern Asian biodiversity hot spots. Geology 46(1): 3-6. https://doi.org/10.1130/G39693.1

Ma HJ, Zhang ST, Su T, Wang L, Sui SG (2012) New materials of Equisetum from the Upper Miocene of Mangkang, eastern Xizang and its ecological implications. Journal of Jilin University 42(suppl. 3): 189-195. [Earth Science Edition]

Skog JE, Dilcher DL (1994) Lower vascular plants of the Dakota Formation in Kansas and Nebraska, USA. Review of Palaeobotany and Palynology 80(1-2): 1-18. https://doi. org/10.1016/0034-6667(94)90089-2

$\mathrm{Su} \mathrm{T}$ (2010) On the establishment of the leaf physiognomy climate model and a study of the late Pliocene Yangjie flora, Southwest China (PhD thesis). Graduate University of the Chinese Academy of Sciences, Beijing.

Su T, Jacques FMB, Liu YS, Xiang JY, Xing YW, Huang YJ, Zhou ZK (2011) A new Drynaria (Polypodiaceae) from the Upper Pliocene of Southwest China. Review of Palaeobotany and Palynology 164(1-2): 132-142. https://doi.org/10.1016/j.revpalbo.2010.11.011

Su T, Jacques FMB, Spicer RA, Liu YS, Huang YJ, Xing YW, Zhou ZK (2013a) Post-Pliocene establishment of the present monsoonal climate in SW China: Evidence from the late Pliocene Longmen megaflora. Climate of the Past 9(4): 1911-1920. https://doi.org/10.5194/ cp-9-1911-2013

Su T, Liu YS, Jacques FMB, Huang YJ, Xing YW, Zhou ZK (2013b) The intensification of the East Asian winter monsoon contributed to the disappearance of Cedrus (Pinaceae) in southwestern China. Quaternary Research 80(2): 316-325. https://doi.org/10.1016/j. yqres.2013.07.001

Sun G, Zheng SL, Dilcher DL, Wang YD, Mei SW (2001) Early angiosperms and their associated plants from western Liaoning, China. Shanghai Scientific and Technological Education Publishing House, Shanghai.

Sun BN, Du BX, Ferguson DK, Chen JL, He YL, Wang YD (2013) Fossil Equisetum from the Lower Cretaceous in Jiuquan Basin, Gansu, Northwest China and its paleoclimatic significance. Palaeogeography, Palaeoclimatology, Palaeoecology 385(1): 202-212. https://doi. org/10.1016/j.palaeo.2013.06.005

Taiz L, Zeiger E (2010) Plant Physiology. $5^{\text {th }}$ Edition. Sinauer Associates Inc., Sunderland.

Wang DM, Hao SG, Wang Q (2005) Rotafolia songziensis gen. et comb. nov., a sphenopsid from the Late Devonian of Hubei, China. Botanical Journal of the Linnean Society 148(1): 21-37. https://doi.org/10.1111/j.1095-8339.2005.00387.x

Wang L, Jacques FMB, Su T, Xing YW, Zhang ST, Zhou ZK (2013) The earliest fossil bamboos of China (middle Miocene, Yunnan) and their biogeographical importance. Review of Palaeobotany and Palynology 197: 253-265. https://doi.org/10.1016/j.revpalbo.2013.06.004

Wang L, Kunzmann L, Su T, Xing YW, Zhang ST, Wang YQ, Zhou ZK (2019) The disappearance of Metasequoia (Cupressaceae) after the middle Miocene in Yunnan, Southwest China: 
Evidences for evolutionary stasis and intensification of the Asian monsoon. Review of Palaeobotany and Palynology 264: 64-74. https://doi.org/10.1016/j.revpalbo.2018.12.007

Watson J, Batten DJ (1990) A revision of the English Wealden flora. II. Equisetales. Bulletin of the British Museum (Natural History), Geology 46: 37-46.

Wu SQ (1999) A preliminary study of the Rehe flora from western Liaoning. Palaeoworld 11(1): 7-37.

Wysocka A, Świerczewska A (2010) Lithofacies and depositional environments of Miocene deposits from tectonically controlled basins (Red River Fault Zone, northern Vietnam). Journal of Asian Earth Sciences 39(3): 109-124. https://doi.org/10.1016/j.jseaes.2010.02.013

Yang XJ (2003) New material of fossil plants from the early Cretaceous Muling Formation of the Jixi Basin, eastern Heilongjiang Province, China. Acta Palaeontologica Sinica 42: 561-584.

Yang GL, Wang ZX, Chen JW, Yan DF, Sun BN (2016) Equisetum cf. oppositum (Equisetaceae) from the Paleocene-Eocene of Tibet in southwestern China and its paleo environmental implications. Arabian Journal of Geosciences 9: 749. https://doi.org/10.1007/s12517$016-2777-z$

Zeiller R (1903) Flore fossile des gîtes de charbon du Tonkin: Texte. Imprimerie Nationale, Paris. https://doi.org/10.5962/bhl.title.64389

Zhang YL, Ferguson DK, Ablaev AG, Wang YF, Li C-S, Xie L (2007) Equisetum cf. pratense (Equisetaceae) from the Miocene of Yunnan in Southwestern China and its paleoecological implications. International Journal of Plant Sciences 168(3): 351-359. https://doi. org/10.1086/510411 